\title{
Sustainable Concept and Economic Evaluation of a Solar-Powered Hydrogen Generation Unit
}

\author{
Laura Langenbucher ${ }^{1, * *}$, Lukasz Brodecki ${ }^{2}$, Michael Wiesmeth ${ }^{2}$, Ines Klugius ${ }^{1}$, \\ Heiner Hüppelshäuser ${ }^{1}$, Markus Bles| ${ }^{2}$, Ralf Wörner ${ }^{1}$

\begin{abstract}
${ }^{1}$ Institute of Sustainable Energy Engineering and Mobility, University of Applied Science Esslingen, Kanalstraße 33, Esslingen am Neckar, 73728, Germany

${ }^{2}$ Department of System-analytical methods and Heat Market, Institute of Energy Economics and Rational Energy Use, University of Stuttgart, Heßbrühlstraße 49a, Stuttgart, 70565, Germany
\end{abstract}

*Corresponding author: E-mail: laura.langenbucher@hs-esslingen.de; Tel.: (+49) 7113973298

DOI: 10.5185/amlett.2020.061527

This study focuses on an overall energy consumption prediction for the area of Stuttgart city in Germany and a specific analysis of a solar-fed power-to-gas plant in an industrial area close to Stuttgart. In order to achieve decarbonisation targets, a sustainable concept of hydrogen production and mobility based on renewable energy and a zero-emissions scenario was defined. First, an energy system analysis was conducted to assess the viability of hydrogen as fuel in the system context. Scenario results indicate the increased penetration rate of electric mobility with systematic repercussions on other traffic, power generation and consumption as well as the achievement of the local targets for the reduction of greenhouse gas emissions. As a result, this allows us to make an assessment regarding the relative advantages of hydrogen over alternative propulsion technologies. In a second step, the minimum purchase costs of hydrogen are determined, based on a total-cost-ofownership calculation for an individual energy plant application. In a last chapter of this work, a study was conducted on a zero-emission bus fleet using the total costs of mobility method. The results of this study serve a pioneering role model in urban areas and shall be transferable to projects throughout Europe.

\section{Introduction}

Germany's ongoing efforts to reduce greenhouse gas emissions require a comprehensive transformation of the energy sector, specifically in areas of space heating, electricity and mobility. Hydrogen produced from renewable energy is ideal for applications in these sectors due to its storage capability and its multifaceted usage options and can thus be an essential contribution towards the so called German energy revolution ("Energiewende").

In order to achieve the aspired climate targets, a master plan for $100 \%$ climate protection was developed for the city of Stuttgart. Besides the requirement of a comprehensive energy transition of the electricity and heat system the results reveal the need of a transformation of the mobility sector until 2050 to achieve the set mitigation goals [1]. Further analyses with the optimization model TIMES Local for the city of Stuttgart show the necessity of a transition specifically towards electromobility [2].

An industrial area in the greater Stuttgart area, Germany, is to fulfil these aforementioned premises for $100 \%$ climate protection. For this reason, the city specifies that photovoltaic must cover at least $50 \%$ of the roofs of all buildings in the area. Due to the large roof space of 40.000 square meters, which exceeds the limit that obliges to direct marketing according the German
Renewable Energy Act, new concepts for electricity use of renewable energy plants should be developed. Possible concepts for the purchase of electricity in a stored form, such as hydrogen or methane, were developed. Focus of this paper is a zero-emission local public transport, as this ensures the basic utilization of the further mentioned components.

A solar-powered polymer electrolyte membrane (PEM) electrolyzer with a rated output of at least one megawatt generates hydrogen, used in public transport. Similar hybrid hydrogen generation units are discussed in [3-5]. The hydrogen produced is then stored at a quality level of $\geq 99.999 \%$ (quality class 5) at a pressure level of 200 bar in tanks. Afterwards, the product, compressed to 350/700 bar, will be sold to consumers of public transport at filling stations. In a previous study, different consumer concepts were developed (Fig. 1).

This paper presents the advantages of large-scale industrial hydrogen production plants and analyses the techno-economic aspects of a subsequent hydrogen utilization in public transport. A techno-economic hybrid energy system of a micro grid with four energy sources is considered by Garcia et al. [6]. Zerrahn et al. [7] validate the necessity of energy storages in Germany and calculate the nationwide economy, whereas this paper discusses the 


\section{Advanced Materials Letters www. vbripress.com/aml}

economic viability of a local industrial plant. Also [8] assess solutions in the areas of techno-economic, environmental and safety in hydrogen powered community microgrids in Canada. [9] and [10] include the techno-economic view in the energy management of a hybrid standalone and grid-connected energy system. The results of [11] shows the economic point of view of a small energy generation by a prosumer. Furthermore, Isa et al. [12] values the economics of the previously explained energy system combined with a heat extraction. None of the cited papers discusses the subsequent use of hydrogen for an overall economic concept.

The results of the study should give an insight into the difficulties of the (German) hydrogen economy and point out the technological necessities to achieve economic efficiency. The aim is to define a possible sustainable energy concept according to the premises of the TIMES forecast as well as an economic aspects of energy supplier.

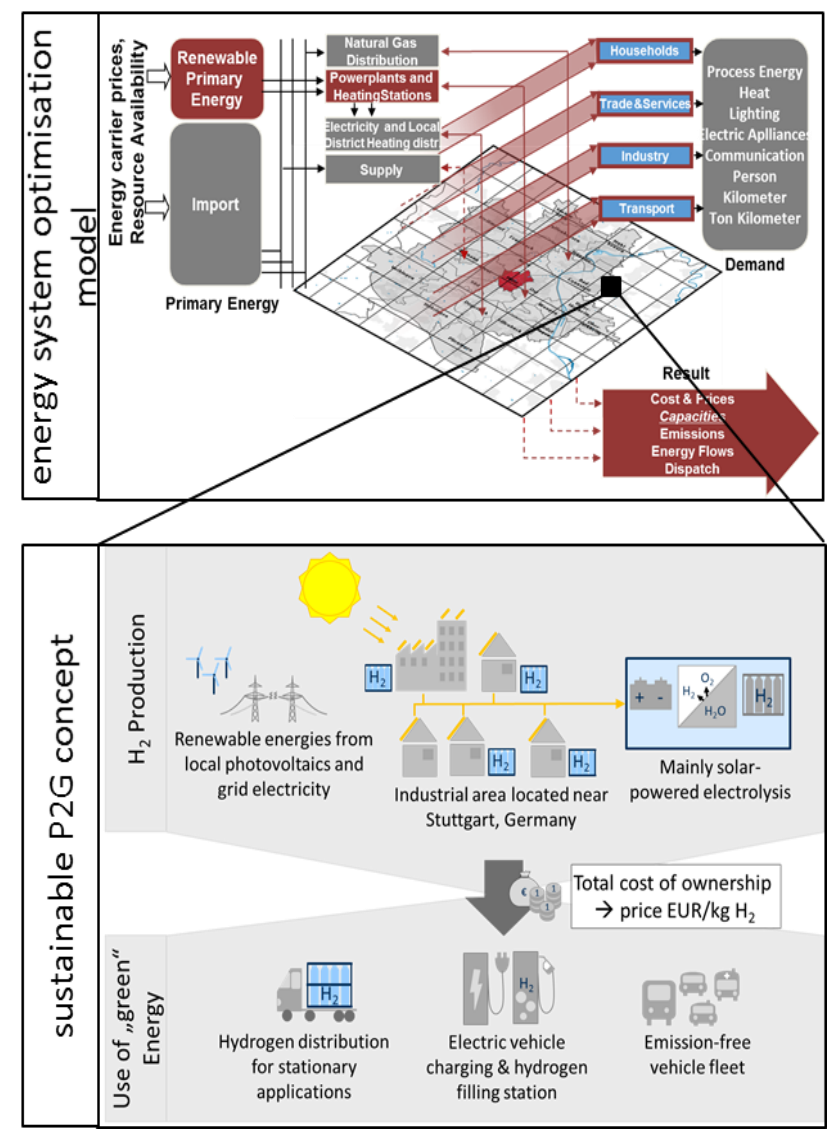

Fig. 1 Sustainable concept of an urban solar-powered hydrogen generation unit.

\section{Results and discussion}

\section{The TIMES Local Stuttgart Model}

The basis of the approach is the model TIMES Local, derived from the TIMES model generator [13]. An energy system is mapped in bottom-up technological detail as a network of processes (e.g. power plant types, transport technologies), goods (energy sources, materials) and the resulting emissions in the form of a reference energy system aggregated in one node. In the linear optimization model, the system base, future demand in the individual sectors and primary energy source prices as well as the parameters characterizing the technologies and energy sources are specified. The objective of the model is an integral expansion and deployment planning of the energy system under the premise of cost minimization. TIMES Local is an application which focuses on considering those processes relevant for a city or a district, thus in this study an analysis was conducted for the City of Stuttgart including the sectors of public electricity and heat supply, private households, trade, commerce, services, transportation, industry and the imports of energy sources [14]. As part of the optimization, an integral expansion and deployment optimization are carried out over the entire modeling period in perfect foresight. The modelling horizon consists of 5-year steps from the year 2010 to 2050. The time resolution is divided into five type weeks with hourly time increments. Four type weeks each correspond to a season (672 time increments per year), and the fifth characterizes a peak week with an hourly resolution (an additional 168 time increments per year) to illustrate a high feed-in of fluctuating renewable energies. Reference year for weather data and generation profiles is the year 2011. Detailed information regarding the model can be found in [13-15]. The focus of scenario analysis is the evaluation of the development of this energy system under consideration of an increased penetration rate of electric mobility, which has systematic repercussions on other traffic, the overall power generation and consumption as well as the achievement of local greenhouse gas emission reduction targets. The study is based on assumptions given by the master plan for the City of Stuttgart, which includes a $\mathrm{CO}_{2}$ cap for each of the model years. The overall goal is a reduction of $\mathrm{CO}_{2}$ emissions by $95 \%$ in 2050 compared to 1990 [1]. In the "KLIMPLUS" scenario, assumptions regarding a decreasing demand for mobility in motorized private transport and a modal shift to local public transport and rail transport are implemented in the scenarios, according to the master plan. At the same time, a partial shift of freight traffic from road to rail is taking place. The use of biofuels will be discontinued from 2040 due to the environmental repercussions of these fuels. The increase of the number of electric vehicles is set until 2030 and is based on the observations and forecasts of the market penetration of electric vehicles (BEV) and plug-in hybrid vehicles (PHEV), referred to as $\mathrm{xEV}$ vehicles in [16]. Explicit targets for the expected penetration of electric mobility are set for the year 2030 - in the years to come, however, the further course of development will be a model endogenous decision. The second scenario named "KLIMPLUS-LOW" contains identical general conditions to "KLIMPLUS", but a significantly delayed and slowed development of electro mobility until 2030 is assumed and investigated. 


\section{Advanced Materials Letters www. vbripress.com/aml}

Table 1. Scenario definition regarding market penetration of xEV based on [16].

\begin{tabular}{c|c|c|c|c}
\hline $\mathbf{2 0 3 0}$ & & BEV & PHEV & xEV Share \\
\hline \multirow{4}{*}{$\begin{array}{c}\text { xEV high } \\
\text { (KLIMPLUS) }\end{array}$} & Cars & $16.47 \%$ & $10.60 \%$ & $27.07 \%$ \\
\cline { 2 - 5 } & Light duty & $11.62 \%$ & n.a. & $11.62 \%$ \\
\cline { 2 - 5 } & Busses & $21.02 \%$ & n.a. & $21.02 \%$ \\
\hline \multirow{4}{*}{$\begin{array}{c}\text { xEV low } \\
(\text { KLIMPLUSLOW) }\end{array}$} & Cars & $3.33 \%$ & $6.67 \%$ & $10.00 \%$ \\
\cline { 2 - 5 } & Light duty & $4.00 \%$ & n.a. & $4.00 \%$ \\
\cline { 2 - 5 } & Busses & $7.00 \%$ & n.a. & $7.00 \%$ \\
\hline
\end{tabular}

\section{Results of the local energy system analysis}

With regard to the development of the transport sector in the city of Stuttgart, one of the main results of our energy system analysis is the development of the final energy consumption:

For both scenarios between 2020 and 2050, the results of the optimization model show a declining trend in final energy consumption (Fig. 2 (a)), albeit at different speeds. Overall, the consumption level of diesel and petrol is declining and this final energy demand is being substituted by electricity in battery electric vehicles. As a result, the overall level of consumption will be greatly reduced, since electric drives are significantly more efficient than internal combustion engines. What is decisive at this point, however, is that regardless of whether we are in the scenario of accelerated (Klimplus) or slowed (Klimpluslow) implementation of electro mobility, the final result in 2050 will be the same. The cost-optimal transport system in Stuttgart will therefore always tend towards more electro mobility in the coming decades under climate protection efforts.

If we subsequently consider the distribution of the final energy demand among the transport modes (Fig. 2 (b)), we can observe that motorized individual transport (cars and motorcycles) initially accounts for the largest share at around $70 \%$. Even in 2050, private motorized transport will remain the largest single group, but its relative share of total consumption will fall to around $50 \%$. This is due the fact that on one hand, in the chosen scenarios a shift from individual transport to public transport is assumed, as well as the fact that most trains are already electrified today, which means that their absolute contribution does not fall, and on the other hand to the fact that while in the future almost all engines in passenger cars will be electric, hydrogen and a residual quantity of diesel with correspondingly lower levels of utilization will still play a role in trucks and buses instead. The relative importance of trucks and buses in total consumption will therefore increase from approximately $20 \%$ (2020) to around $24 \%$ (2050) in the foreseeable future - it will therefore become more important to further concentrate on the analysis of decarbonization options for trucks and buses. (b)
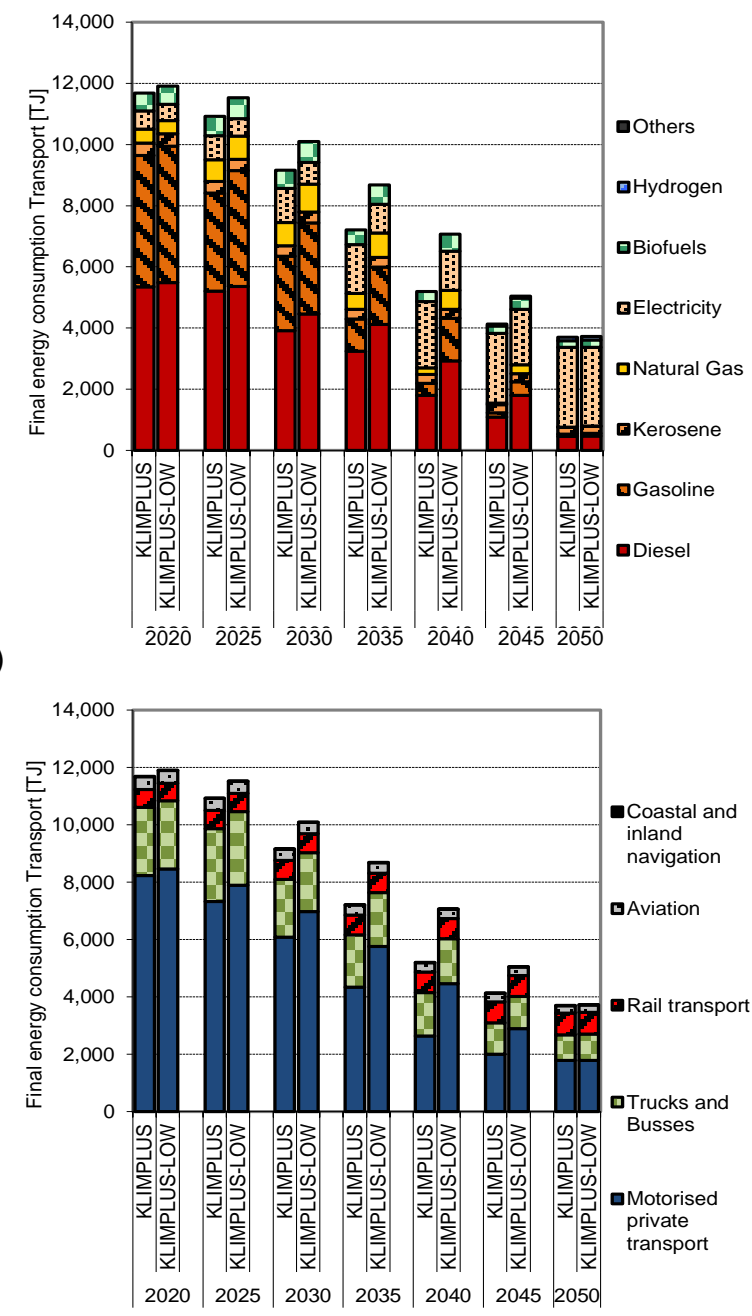

Fig. 2. Final Energy Consumption of Transport by Energy Carrier (a) and by Mode of Transport (b) in the Stuttgart Region (2020 - 2050).

Consider now the final energy consumption of the buses active in Stuttgart for the year 2020 (Fig. 3 (a)). Here we observe that, on the basis of today's stock, the majority of buses are still powered by conventional fuels (diesel, natural gas) or, to a lesser extent, blended biofuels.

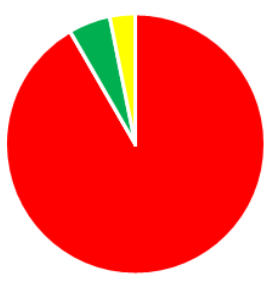

(a)

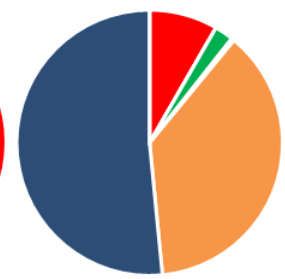

(b)

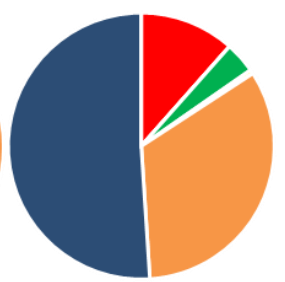

(c)

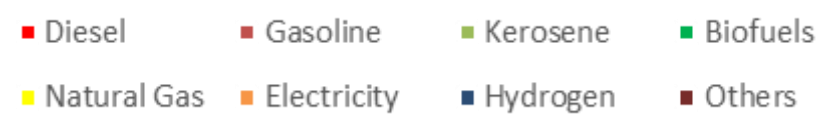

Fig. 3. Final Energy Consumption of Busses by Energy carrier in 2020 (a), 2050 - Klimplus (b) and 2050 - Klimplus-low (c). 


\section{Advanced Materials Letters www. vbripress.com/aml}

For the year 2050, however, we see a distribution in the Klimplus scenario (Fig. 3(b)) that deviates significantly from the initial state, with only small amounts of diesel and biodiesel and instead the two predominant groups of hydrogen and electricity. Both energy sources are used in our model, as buses tend to use hydrogen on longer routes and intercity buses, while electrification predominates on shorter inner-city routes.

The Klimplus-low scenario differs only slightly from this (Fig. 3(c)). Due to the fact that the use of electric mobility and the associated infrastructure development are delayed, we see a slightly higher proportion of vehicles with conventional drives at the expense of electric buses.

Nevertheless, in both scenarios hydrogen plays a decisive role in the decarbonization of bus fleets, which is why in the following we conduct a detailed cost analysis of a hydrogen supply infrastructure for the Stuttgart metropolitan area.

(a)



(b)

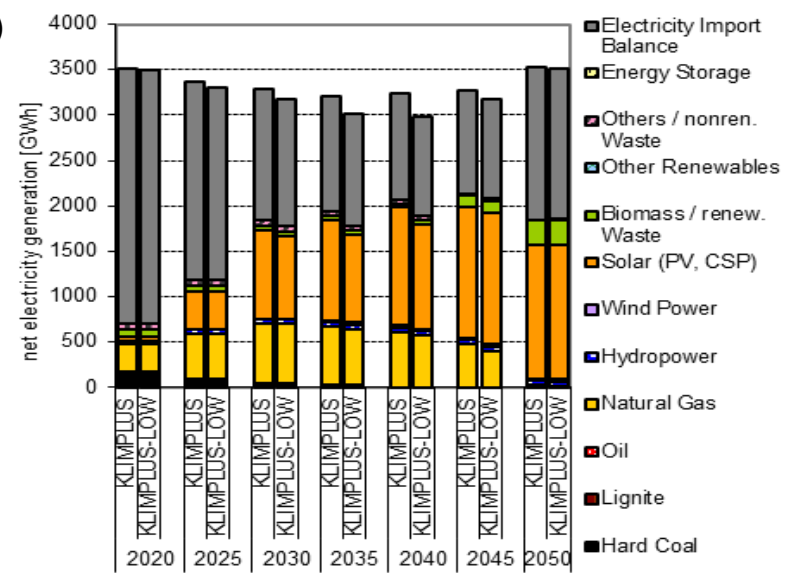

Fig. 4. Electricity Consumption by Sector (a) and Electricity Generation by Energy Carrier in Stuttgart (2020 - 2050).

The effects of increasing electrification (direct electrification and hydrogen use) are reflected in the electricity consumption of the transport sector (Fig. 4(a)). From a small share in total electricity consumption of around 5\% (2020), the share of transport is increasing to between $23 \%$ (direct use of electricity) and $29 \%$ (indirect use of electricity in hydrogen production). Thus, from a system perspective, the transport sector poses new challenges for system design and management (load curve, network load). On the other hand, it simplifies the integration of fluctuating renewable energies as a flexible load under certain circumstances.

A look at the composition of the local electricity supply in the city of Stuttgart (Fig. 4(a)) reveals a predominant dependence on imports (approx. 80\%) at the present time. This import dependency can be successively reduced in the following periods by increased use of natural gas CHP and photovoltaics. Photovoltaics is thus the main, emission-free, local power generation option in the long term.

Earlier results did not consider a decreasing demand for mobility in motorized private transport and a modal shift to local public transport and rail transport [17]. In addition the negligence of infrastructure cost for charging points lead to an overestimation of electric mobility and thus to an unfair evaluation of hydrogen based technologies.

Summarized and related to the transport system of the city, this means that it experiences a pronounced electrification with partial use of hydrogen in buses and trucks, whereby the electricity used for this could come largely from local photovoltaics. In the following chapters, our focus is therefore on the conceptual design of a practical hydrogen supply system based on photovoltaic electricity.

\section{Simulation of the hydrogen generation unit}

A scenario analysis of the hydrogen generation unit considers three expansion levels for electricity procurement. Firstly, hydrogen production in a micro grid with use of photovoltaic electricity from nearby buildings is conducted in scenario 1. Fig. 5(a) shows the power output of a photovoltaic simulation and the performance of the considered PEM electrolyzer. To get a maximum utilization rate throughout the year, the rated power of the PEM electrolyzer is significantly lower than the maximum peak power of the photovoltaic system. The capacity utilization is 2581 full load hours and 52 tons of hydrogen per year. It represents the basic scenario. The combination of the seasonal fluctuation with a consumer proves difficult. An exact list of the selected premises of components of the photovoltaic and the hydrogen generation unit are collected in Table 2.

In addition to the electricity produced from the photovoltaic system, the use of electricity at low tariffs (also known as nighttime electricity) is conducted in scenario 2. The operating time from initially 2581 full load hours per year increases to 5683 hour, and 114 tons of hydrogen are produced. Due to the continuously hydrogen production, it is easier to link generation and storage side with an intensive consumer. However, it must be emphasized that the production takes place mainly at night. In order to maintain the comparability of the three scenarios, the plant components are left in their size. 


\section{Advanced Materials Letters www. vbripress.com/aml}

Nevertheless, based on the premise that there is sufficient electricity capacity at a low tariff, the question of an optimum economic efficiency by increasing the nominal capacity of the PEM electrolyzer should be answered in a further study.

In the third and final scenario, the photovoltaic is combined with the high tariff electricity. According to [18], the capacity utilization of the PEM electrolyzer is then assumed to be $98 \%$ per year. A general maintenance of the PEM electrolyzer and its components is to be carried out in the remaining 180 hours. The full load hours are approximately 8580 hours a year. An annual hydrogen production of 172 tons can be expected. Fig. 5(b) shows the load spectrum of all scenarios. As previously described in scenario 2, the design of the plant should be checked for higher performance.

(a)

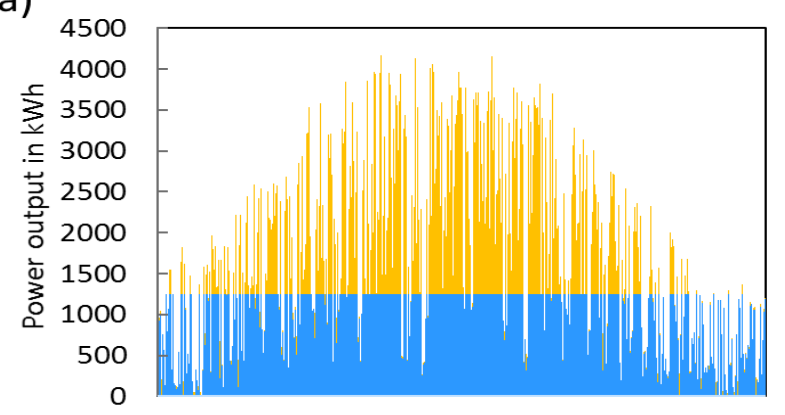

(b)
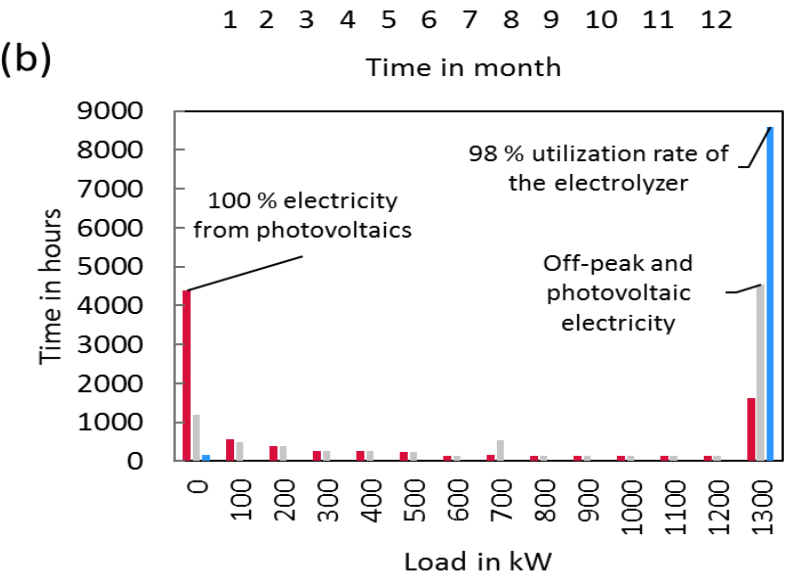

Fig. 5. (a) Simulated photovoltaic power output (yellow) and performance of the electrolyzer (blue) over one year. (b) Load spectrum of three scenarios. Scenario 1 (red), scenario 2 (grey), scenario 3 (blue).

Table 2. Premises of the simulated results.

\begin{tabular}{|c|c|c|c|c|}
\hline TCO & & & & \\
\hline \multirow{4}{*}{ Photovoltaic } & Efficiency [\%] & \multicolumn{3}{|c|}{18} \\
\hline & Alignment & \multicolumn{3}{|c|}{$\mathrm{E} / \mathrm{W} 20^{\circ}$} \\
\hline & Installed Power [MW] & \multicolumn{3}{|c|}{5,6} \\
\hline & Produced [MWh] & \multicolumn{3}{|c|}{4747} \\
\hline \multirow{3}{*}{ Electrolyzer } & Efficiency [\%] & \multicolumn{3}{|c|}{74} \\
\hline & Capacity [kW] & \multicolumn{3}{|c|}{1250} \\
\hline & Utilization [\%] & 29,4 & 64,9 & 98 \\
\hline \multicolumn{5}{|l|}{ TCM } \\
\hline \multirow{4}{*}{$\begin{array}{c}\text { Public } \\
\text { Transport }\end{array}$} & Scheduled kilometers $[\mathrm{km} / \mathrm{a}]$ & \multicolumn{3}{|c|}{348.000} \\
\hline & Consumption $\left[\mathrm{kg} \mathrm{H}_{2} / 100 \mathrm{~km}\right]$ & \multicolumn{3}{|c|}{$9 \mathrm{~kg}$} \\
\hline & CAPEX [EUR/km] & 0,46 & 1,20 & 1,20 \\
\hline & OPEX [EUR/km] & 2,64 & 3,04 & 3,44 \\
\hline
\end{tabular}

The total costs of ownership and total costs of mobility analysis

A Total Cost of Ownership (TCO) and a Total Costs of Mobility (TCM) analysis follow the before described simulation. All costs are calculated without a government funding. Firstly, in the Total Costs of Ownership analysis, a developed Excel tool calculates the CAPEX and OPEX costs of the hydrogen generation unit. Using data, which was previously obtained, gives the previously simulated results, which are presented in Fig. 6(a). The abscissa shows the net price of hydrogen per kilogram. The ordinate shows the static amortization time of the hydrogen generation unit in years. As described above, four scenarios are considered:

- Scenario 1: Micro grid operation (red line)

- Scenario 2: PV + low tariff electricity between 22:0006:00 (blue line)

- Scenario 3: PV + high tariff electricity between 22:00-06:00 (light blue line)

- Scenario 4: $98 \%$ utilization of the PEM electrolyzer (grey line)

The operator's target is a static payback period of less than 20 years. Due to the situation that the electricity produced by the photovoltaic does not cross any districts of the industrial area, there is no need of paying taxes and duties. Hence, the photovoltaic system is priced in via the investment costs and the maintenance costs according to VDI 2067. However, the photovoltaic electricity is not sufficient to generate an adequate amount of hydrogen to operate the generation unit economically at the current market price in Germany of EUR 8,40/ $/ \mathrm{kg} \mathrm{H}_{2}$ net and EUR 9,50/kg H 2 gross (Fig. 6 (a)).

As a result, the hydrogen economy is impelled to couple electricity from operator's photovoltaic with electricity from the public grid. Therefore, in further scenarios 2, 3 and 4, electricity is purchased at high and low tariffs, i.e. day and night, for the production of hydrogen. Scenarios 3 and 4 are based on the high tariff price per kilowatt-hour for large customers with a consumption of over 100,000 kWh in Germany. In scenario 2, the price per kilowatt-hour is reduced up to $30 \%$ compared to scenarios 3 and 4 due to the low tariff electricity purchase [19-21]. Due to dynamic start-up and shut-down processes of flexible power plants, i.e. future gas power plants, a division of electricity tariffs into high and low tariffs at fixed times will probably no longer be possible after successful implementation of the energy system transformation.

Scenario 4 does not achieve static amortization at a price of $7 \mathrm{EUR} / \mathrm{kg} \mathrm{H} \mathrm{H}_{2}$ net since the costs of hydrogen production exceed the possible revenues. The significant degression in this scenario compared to the other static amortization scenarios between $8 \mathrm{EUR} / \mathrm{kg} \quad \mathrm{H}_{2}$ and 9 EUR $/ \mathrm{kg} \mathrm{H}_{2}$ is justified by the higher hydrogen production. The margin achieved between production costs and sales is multiplied in scenario 4 by more than $330 \%$ of the hydrogen produced in scenario 1 . 


\section{Advanced Materials Letters www. vbripress.com/aml}

(a)

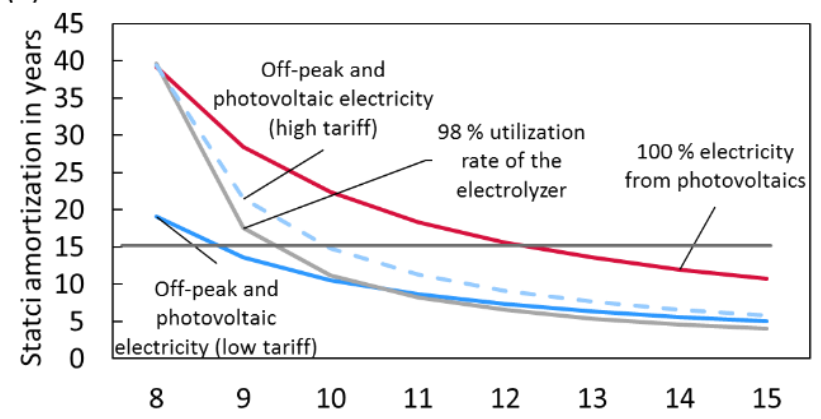

(b)

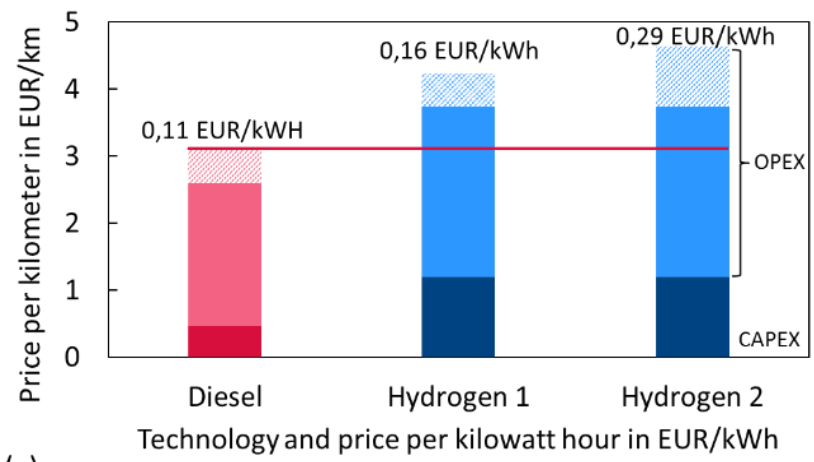

(c)

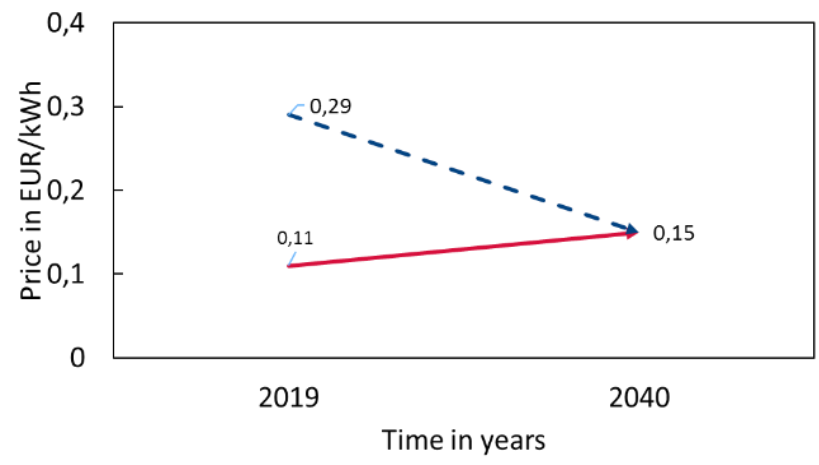

Fig. 6. (a) Static amortization of the hydrogen generation unit calculated with different marginal costs in a TCO analysis. (b) TCM calculation of a bus fleet with different hydrogen prices. (c) Present and future diesel (red) and present hydrogen (blue) prices.

A hydrogen price of at least $8 \mathrm{EUR} / \mathrm{kg} \mathrm{H}_{2}$ can be derived in scenario 2. This price is taken up in the subsequent TCM calculation. Summarized, Fig. 6(a) shows that the use of the low tariff electricity according to current considerations, represents a possible optimum of an economic point of view. It can therefore be concluded that coupling of the micro grid with the public electricity grid is a basic prerequisite for sufficient capacity utilization of the hydrogen generation unit and thus for economic efficiency in the hydrogen economy. Future studies might extend the simulation tool with an implementation of energy market models.

To complete value-added chain of a sustainable hydrogen concept, a Total Costs of Mobility analysis of an emission-free public transportation, which is recommended e.g. by [22], is carried out and the results are shown in Fig. 6(b). An Excel tool calculates the
CAPEX (dark red/blue) and OPEX (light red/blue) costs of a fuel cell bus per kilometer. Further information on the premises is listed in Table 2. The CAPEX costs of a bus are described in this study by investments in diesel or emission-free fuel cell buses. The OPEX costs of the site consist of following components:

- Fuel costs

- Bus/infrastructure maintenance

- Bus insurance

- Administration

- Staff

The costs per kilometer of two selected hydrogen cases are compared with those of a diesel bus. The fuel costs are converted into euro per kilowatt-hour in order to be able to draw a comparison between the energy costs.

In the case of "Hydrogen 1", annual fuel costs of 5,30 euro per kilogram hydrogen gross $(0,16 \mathrm{EUR} / \mathrm{kWh})$ of hydrogen are equivalent to the diesel fuel costs of 1,11 euro per liter gross $(0,11 \mathrm{EUR} / \mathrm{kWh})$. However, due to considerable differences in the efficiency of drive technologies, hydrogen costs per kilowatt-hour are higher than diesel [23]. We calculate with a hydrogen consumption of $9 \mathrm{~kg} \mathrm{H} / 100 \mathrm{~km} \mathrm{[24].} \mathrm{The} \mathrm{results} \mathrm{from}$ Fig. 6(b) show that fuel cell technology with a $60 \%$ higher CAPEX and a $25 \%$ higher OPEX is more cost-intensive than a diesel-powered bus per kilometer. Moreover, this does not correspond to the marginal costs calculated previously in Fig. 6(a), which are at least $8 \mathrm{EUR} / \mathrm{kg} \mathrm{H}$ per kilogram. Therefore, we do not see the case "Hydrogen 1" as a marketable consumer scenario in the hydrogen economy.

In a second case "Hydrogen 2", merchantable fuel costs are estimated with $8 \mathrm{EUR} / \mathrm{kg} \mathrm{H}_{2}$ net or $9,50 \mathrm{EUR} / \mathrm{kg}$ $\mathrm{H}_{2}$ gross $(0,29 \mathrm{EUR} / \mathrm{kWh})[\mathbf{2 3 , 2 5}]$, so that a static amortization period of approximately 19 years is possible for the operator of the hydrogen generation unit. The cost per kilometer of the fuel price is $9 \%$ higher than in the case of "Hydrogen 1". The fuel cell bus increases 33\% compared to the diesel bus. Since the hydrogen production costs are covered, it is a sustainable energy concept in the hydrogen economy, provided the conditions in the following paragraph are met.

Fig. 6(c) shows the present and future diesel (red) and present hydrogen (blue) prices in Germany $[\mathbf{1 8 , 2 3 , 2 5 - 2 8}$. The fuel costs of diesel and hydrogen are compared with the literature and verified by the experience of two regional bus operators. One target of the hydrogen economy might be to reduce the production costs of hydrogen in order to achieve equivalence with the future fuel costs of a diesel bus. This can be done by reducing the production costs of the components of a hydrogen generation unit and by implementing a highly efficient two level control, which combines predictive and swarm optimization algorithms. In addition, the future production costs of the fuel cell bus must be reduced in order to achieve a sustainable, economic hydrogen economy as well as cost equivalence. 


\section{Advanced Materials Letters www. vbripress.com/aml}

\section{Conclusion}

A sustainable concept of a solar-powered hydrogen generation unit is developed under the prospective premises of the Masterplan of Stuttgart. The total costs of ownership calculation provides a minimum price of 8 EUR/kg $\mathrm{H}_{2}$ net to achieve a static payback period of 19 years. The total costs of mobility analysis reveals a significant cost difference of the drive technologies. Hence, the energy markets of the producer and consumer should be coupled to cover the value-added chain and to reduce the production costs of hydrogen applications. For today's hydrogen market, a funding of additional costs is necessary. Future research should complete the tools with an energy market model of volatile energy producers as well as taking account of life cycle costs.

Further model-based analysis can be conducted by including a vehicle-to-grid approach in the system, allowing for the implementation of additional flexibility options for the integration of fluctuating renewables. A cost-benefit analysis for different agents can be included. Also additional use cases for electric mobility like the market penetration of overhead-line trucks and their effect on the overall energy system can be included into future analyses.

\section{Acknowledgments}

This work was supported by Funding Program for emission free public transport by fuel cells and hydrogen from the Ministry of the Environmet, Climate Protection and the energy Sector BadenWürttemberg.

\section{Author's contributions}

Conceived the plan: RW, MB, HH, LL; Data analysis: LL, MW, LB; Wrote the paper: LL, MW, LB. Authors have no competing financial interests.

\section{Keywords}

Hydrogen production, renewable energies, emission-free fleet of vehicles, energy systems.

\section{Received: 31 July 2019}

Revised: 25 November 2019

Accepted: 25 November 2019

\section{References}

1. Fraunhofer Institut IBP, Universität Stuttgart. Masterplan 100 \% Klimaschutz der Landeshauptstadt Stuttgart. Stuttgart; 2017.

2. Institut für Energiewirtschaft und Rationelle Energieanwendung Universität Stuttgart, Städtebau-Institut et al. Forschungsvorhaben WECHSEL - Weiterentwicklung der bestehenden Stuttgarter Energieinfrastruktur und resultierende Chancen für die nachhaltige Stadtentwicklung: Förderkennzeichen 01UR1620A,B. Stuttgart; 2019.

3. Laoun, B.; Khellaf, A.; Naceur, M.W.; Kannan, A.M.; International Journal of Hydrogen Energy, 2016, 41, 10120.

4. Sopian K.; Ibrahim M.Z.; Wan Daud W.R.; Othman M.Y.; Yatim B.; Amin N.; Renewable Energy, 2009, 34, 1973.

5. Kelly, N.A.; Gibson, T.L.; Ouwerkerk, D.B.; International Journal of Hydrogen Energy, 2011, 36, 15803.

6. García, P.; Torreglosa, J.P.; Fernández, L.M.; Jurado, F.; Langella, R.; Testa, A.; Electric Power Systems Research, 2016, 131, 49.

7. Zerrahn, A.; Schill, W.P.; Kemfert, C.; European Economic Review, 2018, 108, 259.

8. Mukherjee, U.; Maroufmashat, A.; Ranisau, J.; et al. International Journal of Hydrogen Energy, 2017, 42, 14333.
9. Torreglosa, J.P.; García-Triviño, P.; Fernández-Ramirez, L.M.; Jurado, F.; Expert Systems with Applications, 2016, 51, 59.

10. Maleki, A.; Hafeznia, H.; Rosen, M.A.; Pourfayaz, F.; Applied Thermal Engineering, 2017, 123, 1263.

11. Jarnut, M.; Wermiński, S.; Waśkowicz, B.; Renewable and Sustainable Energy Reviews, 2017, 74, 925.

12. Isa, NM.; Das, HS.; Tan, CW.; Yatim, AHM.; Lau, KY.; Energy, 2016, 112, 75.

13. Remme U.; Goldstein G.; Schellmann U.; Schlenzig C.; MESAP/TIMES- Advanced decision support for energy and environmental planning. Operations Research Proceedings; 2001.

14. Brodecki, L.; Blesl, M.; Modellgestützte Bewertung von Flexibilitätsoptionen und Versorgungsstrukturen eines Bilanzraums mit hohen Energieversorgungsgraden mit Energie; 2018.

15. Welsch J.; Blesl M.; 2. Modellierung von Energiespeichern und Power-to-X-Technologien mit dem europäischen Energiesystemmodell TIMES PanEU. VDI Optimierung in der Energiewirtschaft; 2015.

16. Blesl M.; Wiesmeth M.; Wörner R.; Elektromobilität im urbanen Raum-Analysen und Prognosen im Spannungsfeld von Elektromobilität und Energieversorgung am Fallbeispiel Stuttgart Teil 3. Stuttgart; 2019.

17. Blesl et al. Systemanalysis for urban energy strategies via a modular planning instrument - methodological research and and case studies. 2019.

18. Smolinka T.; Günther M.; Garche J.; NOW-Studie: Stand und Entwicklungspotenzial der Wasserstoffelektrolyse zur Herstellung von Wasserstoff aus regenerativen Energien". Berlin; 2011.

19. Hayn M.; Bertsch V.; Fichtner W.; Stromtarife und Technologien im Endkundenmarkt und deren Einfluss auf den Leistungsbedarf von Haushalten aus dem Netz. uwf. 2014, 22, 249-255.

20. Stromliste. Wie funktionieren die Nachtstromtarife in Österreich? Available at:

https://stromliste.at/strompreis/tarifarten/unterbrechbar/nachtstrom. Accessed July 25, 2019.

21. Stadtwerke Waiblingen GmbH. Preisblatt zu den Sonderverträgen zur Stromlieferung. Available at:

https://stadtwerke-waiblingen.de/index.php/elektrospeicherheizungwaermepumpe.html. Accessed July 25, 2019.

22. e-mobil $\mathrm{BW} \mathrm{GmbH}$ - Landesagentur für Elektromobilität und Brennstoffzellentechnologie. Die Rolle von Wasserstoff in der Energiewende: Entwicklungsstand und Perspektiven.

23. Shell Deutschland Oil GmbH. Shell Wasserstoff-Studie: Energie der Zukunft? Nachhaltige Mobilität durch Brennstoffzelle und $\mathrm{H} 2$. Hamburg; 2017.

24. Van Hool. Produktdatenblatt: FC Bus A330 fuel cell. Available at: www.vanhool.com. Accessed July 26, 2019.

25. Kunith, A.W.; Elektrifizierung des urbanen öffentlichen Busverkehrs. Springer Fachmedien Wiesbaden; 2017.

26. Joule, G.P.; Akzeptanz durch Wertschöpfung: Wasserstoff als Bindeglied zwischen der Erzeugung erneuerbarer Energien und der Nutzung im Verkehrs-, Industrie- und Wärmesektor; 2017.

27. DLR. Prognose zur Preisentwicklung von Rohöl, Benzin, Diesel und Erdgas von 2010 bis zum Jahr 2040; 2013

28. Maus, W.; Ed. Zukünftige Kraftstoffe: Energiewende des Transports als ein weltweites Klimaziel. Berlin, Germany: Springer Vieweg; 2019. 